\title{
KUALITAS HIDUP ORANG DENGAN HIV POSITIF, PENGGUNA NAPZA, DAN MASYARAKAT MISKIN KOTA YANG MENGIKUTI AKTIVITAS STREET SOCCER DI RUMAH CEMARA BANDUNG
}

\author{
Ramdhani Hanwar ${ }^{1}$, Eka Nugraha ${ }^{2}$, Kurnia Eka Wijayanti ${ }^{3}$ \\ Fakultas Pendidikan Olahraga dan Kesehatan \\ Universitas Pendidikan Indonesia \\ email : kurniaeka22@gmail.com
}

\begin{abstract}
Abstrak
Penelitian ini bertujuan untuk mengetahui kualitas hidup orang dengan HIV Positif, pengguna napza, dan masyarakat miskin kota yang mengikuti aktivitas street soccer di Rumah Cemara Bandung. Metode penelitian yang digunakan adalah metode deskriptif. Populasi dan sampel yang digunakan adalah pemain Timnas Homeless World Cup 2015 di Rumah Cemara Bandung terdiri dari 8 orang dengan kriteria 2 orang dengan HIV Positif, 2 orang mantan pengguna napza dan 4 orang masyarakat miskin kota, dengan teknik pengambilan sampling jenuh. Instrumen yang digunakan adalah kuesioner WHOQOL-BREF. Hasil penelitian : adanya peningkatan domain kesehatan fisik besarnya $6 \%$ untuk orang dengan HIV positif ; $18.5 \%$ untuk pengguna napza ; 9.25\% untuk masyarakat miskin kota. Domain kesejahteraan psikologis pada orang dengan HIV positif tidak mengalami peningkatan ; peningkatan untuk pengguna napza besarnya $11 \%$; $9.25 \%$ untuk masyarakat miskin kota. Domain hubungan sosial besarnya $12.5 \%$ untuk orang dengan HIV positif ; $12.5 \%$ untuk pengguna napza ; $10.75 \%$ untuk masyarakat miskin kota. domain hubungan dengan lingkungan besarnya $6.5 \%$ untuk orang dengan HIV positif ; $13.5 \%$ untuk pengguna napza ; $14 \%$ untuk masyarakat miskin kota. Simpulan penelitian menggambarkan telah terjadi peningkatan kualitas hidup pada orang dengan HIV positif, pengguna napza, dan masyarakat miskin kota yang mengikuti aktivitas street soccer di Rumah Cemara Bandung.
\end{abstract}

Kata Kunci : Kualitas hidup, Aktivitas street soccer 


\section{Pendahuluan}

Kualitas hidup adalah "Individual perception of their position in life in the context of the culture an value systems in which they live and in relation to their goals, expectations, standars, and concerns" (WHOQOL Group dalam Lopez and Snyder, 2004). Kualitas hidup berkaitan dengan pencapaian kehidupan manusia yang ideal atau sesuai dengan yang diinginkan. Goodinson dan Singleton ( 2008) mengemukakan definisi kualitas hidup sebagai derajat kepuasan atas penerimaan suasana kehidupan saat ini. Adapun Calman (2008) memberikan satu definisi dari kualitas hidup yang dapat diterima secara umum, yakni perasaan subjektif seseorang mengenai kesejahteraan dirinya, berdasarkan pengalaman hidupnya saat ini secara keseluruhan. King, et al (2012) menyebutkan bahwa 'kualitas hidup adalah tingkatan dimana seseorang merasa senang dengan pilihan-pilihan penting dalam kehidupannya'.

Menurut WHOQOL Group (dalam Lopez dan Snyder, 2004), kualitas hidup memiliki enam domain yaitu (1) kesehatan fisik, (2) kesejahteraan psikologis, (3) tingkat kemandirian, (4) hubungan sosial, (5) hubungan dengan lingkungan dan (6) keadaan spiritual. WHOQOL ini kemudian dibuat lagi menjadi instrument WHOQOLBREF dimana enam dimensi tersebut kemudian dipersempit lagi menjadi empat domain yaitu (1) kesehatan fisik, (2) kesejahteraan psikologis, (3) hubungan sosial, (4) hubungan dengan lingkungan.

Aktivitas jasmani berkontribusi terhadap kualitas hidup, kesehatan psikologikal, dan kemampuan untuk mengimbangi tuntutan kerja fisik. Dampak aktivitas jasmani itu sendiri antara lain dampak fisikal, mental dan sosial. Ada suatu kecenderungan kualitas hidup yang baik tidak mungkin didapatkan tanpa aktivitas jasmani atau olahraga. (Abduljabar, 2011, hlm. 69).

Aktivitas jasmani berupa street soccer merupakan bagian dari permainan sepak bola yang dimodifikasi. Menurut Goldblatt dan Acton (2011, hlm. 36) mengemukakan bahwa "sepak bola jalanan memiliki beragam bentuk, tapi pembeda utama antara jenis sepak bola ini dari varian dalam lapangan, seperti futsal namun menggunakan dinding dan papan bukan garis lapangan". Aktivitas jasmani tersebut tidak hanya sekedar permainan beregu untuk kemenangan, dan prestasi, namun sepak bola dapat dijadikan sebagai alat perubahan terhadap kualitas hidup kaum yang termarginalkan dari kehidupan masyarakat. 
Rumah cemara yaitu sebuah organisasi berbasis komunitas yang berdiri pada tahun 2003 merupakan tempat untuk berbagi pengalaman, kekuatan, harapan serta informasi bagi para pengguna narkoba dan Orang Hidup Dengan HIV/AIDS (ODHA) untuk meningkatkan kualitas hidupnya. Pada tahun 2010 hingga saat ini, Rumah Cemara sebagai National Organizer tim Indonesia untuk berpartisipasi di dalam Homeless World Cup (HWC). Delapan pemain terpilih yang berasal dari kelompok yang termarjinalkan seperti mantan pengguna napza, orang yang hidup dengan HIV, masyarakat miskin kota, mantan narapidana, dll.

Kejuaraan dunia street soccer yaitu Homeless World Cup (HWC) yang diadakan untuk memperbaiki permasalahan sosial terkait ketunawismaan seperti pengguna napza, orang dengan HIV-AIDS, kemiskinan, dan kurangnya akses pada pendidikan. Kejuaraan HWC diadakan setiap tahun, sebuah kompetisi sepak bola internasional, yang mempersatukan lebih dari 300.000 orang-orang yang memiliki permasalahan terkait ketunawismaan dan yang termarjinalkan secara sosial untuk mendapatkan kesempatan sekali seumur hidupnya dan mewakili negaranya serta mengubah kehidupannya.

Di Indonesia sering kali menghadapi masalah sosial bagi orang dengan HIV Positif, pengguna napza, dan masyarakat miskin kota yang dianggap marginal oleh masyarakat disekitarnya. Kaum marginal dalam hal ini antara lain orang dengan HIV Positif, pengguna napza, dan masyarakat miskin kota menyadari bahwa kerap kali mendapatkan masalah sosial disekitar lingkungan masyarakat. Kurangnya dukungan dan perhatian yang dapat mempengaruhi kaum marjinal itu sendiri sulit bersosialisasi dengan lingkungan dan masyarakat, bahkan mempengaruhi untuk mendapatkan pengobatan sehingga secara psikologis pun tidak sejahtera. Hal tersebut berdampak pada kualitas hidup kaum marginal tersebut. Sehingga Rumah cemara menggunakan street soccer sebagai alat untuk meningkatkan kualitas hidup ODHA, pengguna napza, dan masyarakat miskin kota.

\section{Metode}

Penelitian ini menggunakan metode deskriptif, dengan tujuan utama untuk menggambarkan secara sistematis fakta dan karakteristik objek atau subjek yang diteliti secara tepat 


\section{Populasi dan Sampel}

Pada penelitian ini populasi yang dijadikan objek penelitian adalah pemain Timnas Homeless World Cup 2015 di Rumah Cemara Bandung. Sedangkan sampel pada penelitian ini adalah 8 orang yang akan berangkat mewakili Indonesia dalam tunamen Homeless World Cup 2015 di Amsterdam, Belanda. Dengan kriteria 2 orang HIV Positif, 2 orang mantan pengguna napza dan 4 orang masyarakat miskin kota.

\section{Instrument}

Dalam penelitian ini, peneliti menggunakan instrumen atau alat ukur World Health Organization Quality of Life - Bref (WHOQOL - BREF). Jumlah item pada alat ukur ini sebanyak 26 item. Item pertanyaan WHOQOL-BREF terdiri dari dua item generik (overall QOL dan general health), dan 24 item yang merupakan penjabaran dari empat dimensi, yaitu kesehatan fisik (7 item), kesejahteraan psikologis (6 item), hubungan sosial (3 item) dan hubungan dengan lingkungan (8 item).

\section{Hasil}

1. Pembahasan Data Domain Kualitas hidup Timnas Homeless World Cup 2015 dengan Kriteria Orang dengan HIV Positif.

Berdasarkan hasil perhitungan presentase skor tiap domain yang telah ditransformasikan ke dalam alat ukur WHOQOL-100, maka diperoleh beberapa data sebagai berikut : 


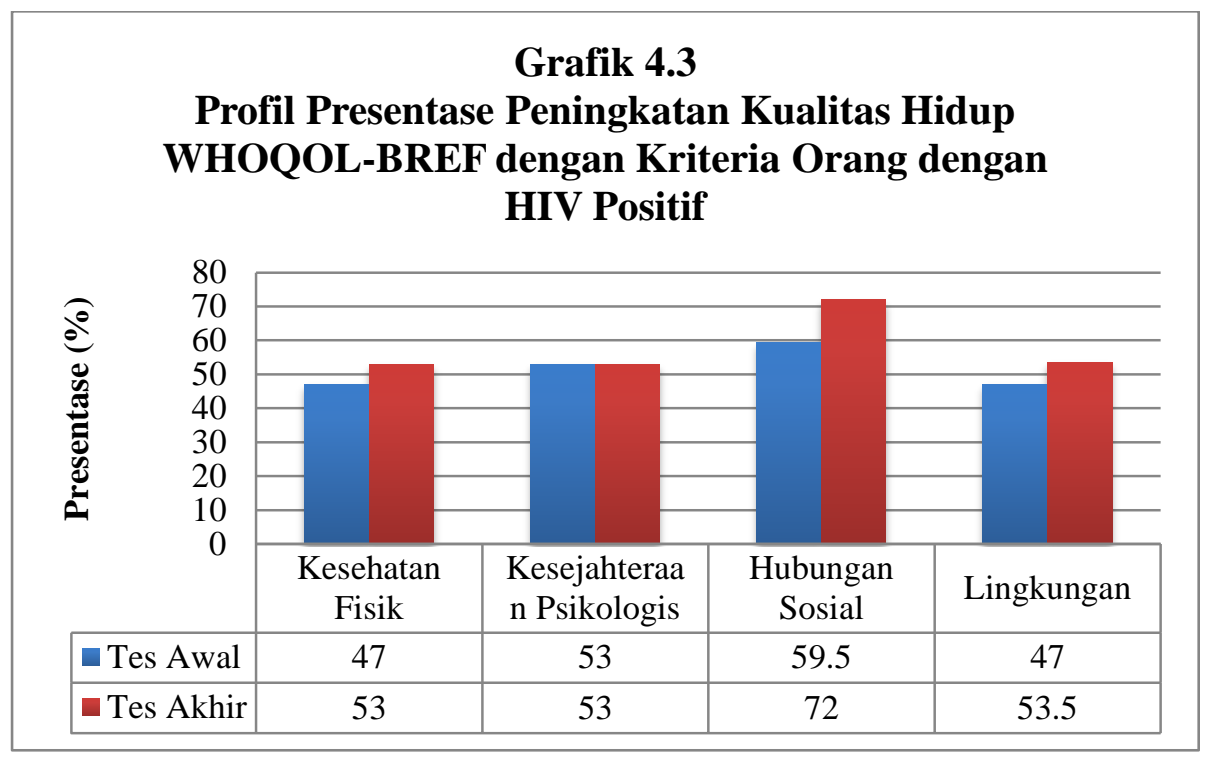

Dapat dilihat dari grafik di atas, skor domain hubungan sosial merupakan skor dengan presentase peningkatan terbesar bagi orang dengan HIV positif dalam Timnas Homeless World Cup 2015 dengan skor peningkatan sebesar 12.5\%.

2. Pembahasan Data Domain Kualitas hidup Timnas Homeless World Cup 2015 dengan Kriteria Pengguna NAPZA.

Berdasarkan hasil perhitungan presentase skor tiap domain yang telah ditransformasikan ke dalam alat ukur WHOQOL-100, maka diperoleh beberapa data sebagai berikut :

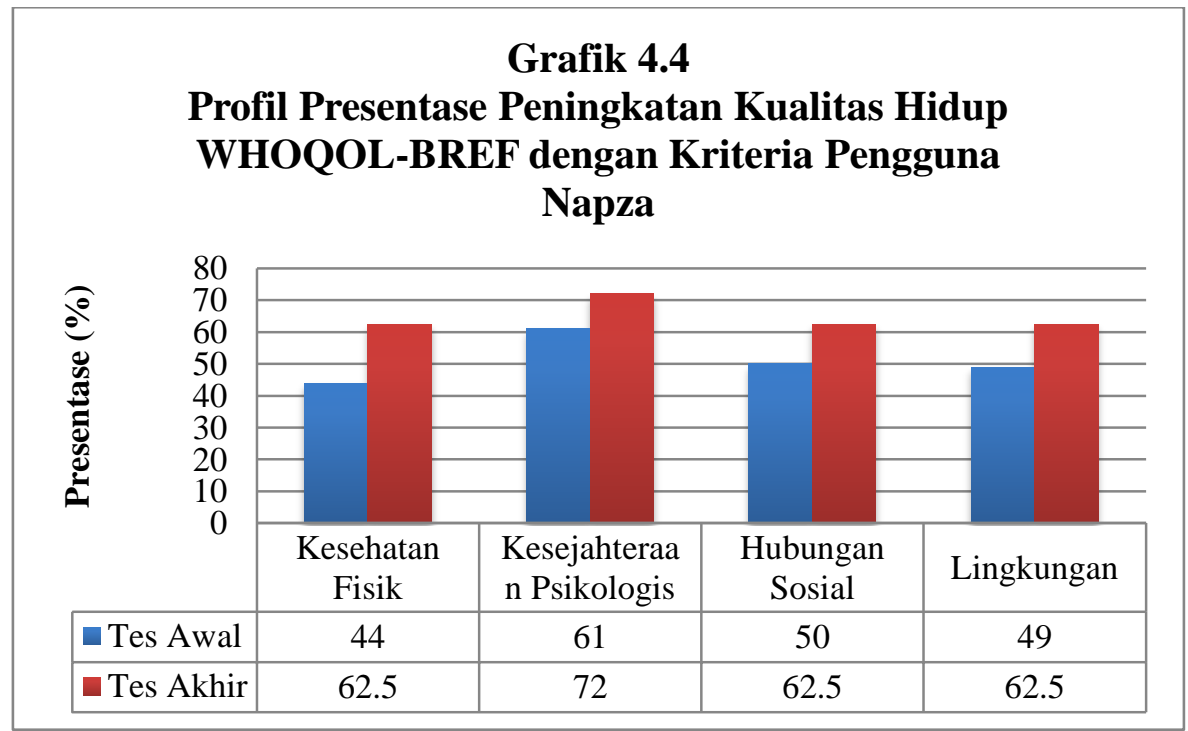


Dapat dilihat dari grafik di atas, skor domain kesehatan fisik merupakan skor dengan presentase peningkatan terbesar bagi pengguna napza dalam Timnas Homeless World Cup 2015 dengan skor peningkatan sebesar 18.5\%.

3. Pembahasan Data Domain Kualitas hidup Timnas Homeless World Cup 2015 dengan Kriteria Masyarakat Miskin Kota.

Berdasarkan hasil perhitungan presentase skor tiap domain yang telah ditransformasikan ke dalam alat ukur WHOQOL-100, maka diperoleh beberapa data sebagai berikut :

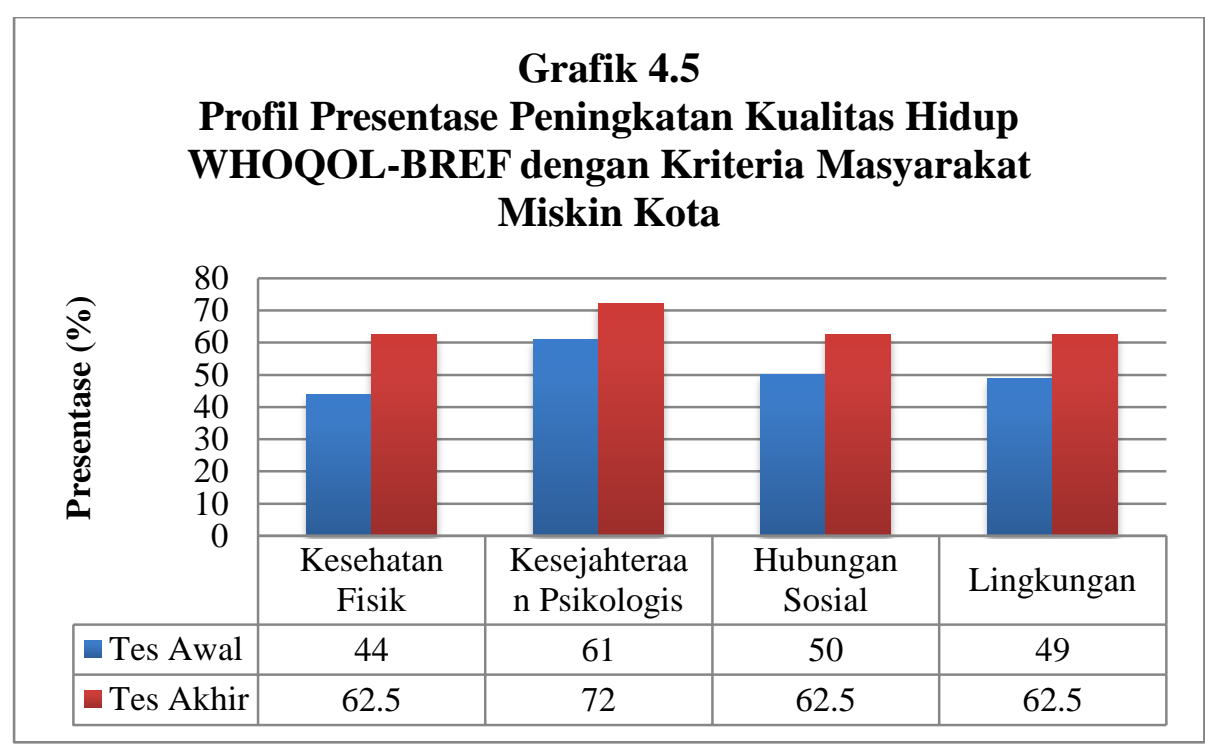

Dapat dilihat dari grafik di atas, skor domain hubungan dengan lingkungan merupakan skor dengan presentase peningkatan terbesar bagi masyarakat miskin kota dalam Timnas Homeless World Cup 2015 dengan skor peningkatan sebesar $14 \%$.

\section{Pembahasan}

Diketahui peningkatan domain kesehatan fisik besarnya $6 \%$ untuk orang dengan HIV positif ; $18.5 \%$ untuk pengguna napza ; 9.25\% untuk masyarakat miskin kota. Domain kesehatan fisik merupakan skor dengan presentase peningkatan terbesar bagi pengguna napza dalam Timnas Homeless World Cup 2015 dengan skor peningkatan sebesar $18.5 \%$. Hal ini menggambarkan kualitas hidup dari segi kesehatan fisik orang dengan HIV Positif, pengguna napza dan masyarakat miskin kota yang sedang melakukan aktivitas street soccer mengalami peningkatan. Hal tersebut dipengaruhi oleh aktivitas jasmani yang dilakukan responden secara teratur sebanyak 6 kali 
seminggu yang dilakukan selama satu bulan baik di pagi hari dan sore hari. Aktivitas jasmani baik berupa street soccer maupun aktivitas lainnya yang dilakukan pada pagi dan sore hari tersebut dapat meningkatkan dan menjaga kebugaran serta kesehatan fisik orang dengan HIV Positif, pengguna napza dan masyarakat miskin kota. Selama beraktivitas street soccer, perasaan resah yang dirasakan individu yang menyebabkan individu merasa sakit dan tidak berguna dapat berubah menjadi perasaan yang menyenangkan karena dapat melakukan aktivitas yang digemari bersama-sama. Hal tersebut sesuai dengan penjelasan Abduljabar (2011, hlm. 65) mengungkapkan bahwa terdapat hubungan erat antara aktivitas jasmani, kebugaran, dan kesehatan. Ketiganya saling mempengaruhi satu dengan yang lain. Orang yang aktif merasakan bugar dan sehat; orang yang sehat dan bugar terbuka peluang untuk meningkatkan aktivitas jasmani. Olahraga baik untuk kesehatan, karena latihan jasmani dalam kegiatan olahraga memiliki pengaruh pada indikator kesehatan, seperti penurunan lemak, tekanan darah, kadar glukosa darah, dan tingkatan insulin dalam tubuh.

Diketahui domain kesejahteraan psikologis pada orang dengan HIV positif tidak mengalami peningkatan ; peningkatan untuk pengguna napza besarnya $11 \% ; 9.25 \%$ untuk masyarakat miskin kota. Menurut Abduljabar (2011, hlm.69) menjelaskan bahwa olahraga dan aktivitas jasmani yang dilakukan secara regular meningkatkan status fungsional dan batas ketidakmampuan kini, kemudian, dan masa mendatang. Aktivitas jasmani berkontribusi terhadap kualitas hidup, kesehatan psikologikal, dan kemampuan untuk mengimbangi tuntutan kerja fisik.

Diketahui peningkatan domain hubungan sosial besarnya $12.5 \%$ untuk orang dengan HIV positif ; $12.5 \%$ untuk pengguna napza ; $10.75 \%$ untuk masyarakat miskin kota. Domain hubungan sosial merupakan skor dengan presentase peningkatan terbesar bagi orang dengan HIV positif dalam Timnas Homeless World Cup 2015 dengan skor peningkatan sebesar $12.5 \%$. Hal ini menggambarkan kualitas hidup dari segi hubungan sosial orang dengan HIV positif, pengguna napza dan masyarakat miskin kota yang sedang melakukan aktivitas street soccer mengalami peningkatan. Hal ini dapat dipengaruhi oleh adanya dukungan sosial rekan-rekan di Rumah Cemara, keluarga, masyarakat dan lingkungannya tanpa ada stigma dan diskriminasi yang melekat pada orang dengan HIV positif, pengguna napza dan masyarakat miskin kota ketika 
bergabung dalam Timnas Homeless World Cup dan melakukan aktivitas jasmani berupa street soccer.

Diketahui peningkatan domain hubungan dengan lingkungan besarnya $6.5 \%$ untuk orang dengan HIV positif ; 13.5\% untuk pengguna napza ; 14\% untuk masyarakat miskin kota. Domain hubungan dengan lingkungan merupakan skor dengan presentase peningkatan terbesar bagi masyarakat miskin kota dalam Timnas Homeless World Cup 2015 dengan skor peningkatan sebesar 14\%. Hal ini menggambarkan kualitas hidup dari segi hubungan dengan sosial orang dengan HIV positif, pengguna napza dan masyarakat miskin kota yang sedang melakukan aktivitas street soccer mengalami peningkatan. Hal tersebut dapat dipengaruhi oleh partisipasi dan kesempatan untuk melakukan rekreasi atau kegiatan yang menyenangkan, menggambarkan individu memiliki kesempatan dan dapat bergabung untuk berekreasi dan menikmati waktu luang, tentunya berkaitan dan melalui aktivitas street soccer yang dilakukan selama tergabung dalam Timnas Homeless World Cup 2015 di Rumah Cemara Bandung. Hal tersebut sesuai dengan penjelasan Zakrajsek (1991) menjelaskan bahwa "olahraga merupakan wahana untuk mengalami aspek pengalaman manusiawi”. Pengalaman yang bersifat manusiawi itu dialami dalam dunia kehidupan nyata, sehingga eksistensi kegiatan olahraga pada hakikatnya merupakan bagian dari kehidupan.

\section{Kesimpulan}

Berdasarkan hasil penelitian, pengolahan dan analisis data menggambarkan telah terjadi peningkatan kualitas hidup pada orang dengan HIV positif, pengguna napza, dan masyarakat miskin kota yang mengikuti aktivitas street soccer di Rumah Cemara Bandung. 


\section{Referensi}

Abduljabar, B. (2011). Pendagogi Olahraga. Bandung : FPOK Universitas Pendidikan Indonesia.

Lutan, R. dkk. (2001). Pendidikan Kebugaran Jasmani : Orientasi pembinaan di sepanjang hayat. Jakarta : Direktorat Jenderal Olahraga, Depsiknas.

Abduljabar, B \& Darajat, J. (2013). Aplikasi Statistika dalam Penjas. Bandung : FPOK Universitas Pendidikan Indonesia.

Nurhasan, (2013). Teori Dan Pengukuran Dalam Pendidikan Jasmani. STKIP Pasundan Cimahi.

Sugiyono. (2013). Metode Penelitian Pendidikan (Pendekatan Kuantitatif, Kualitatif, dan $R \& D)$. Bandung : Alfabeta.

Sjafari, Agus. (2014). Kemiskinan dan Pemberdayaan Kelompok. Yogyakarta : Fisip Untirta Press.

Suci, E.S.T. dkk. (2015). Long and Winding Road, Jalan Panjang Pemulihan Pecandu Narkoba. Jakarta : Buku Kompas.

Sucipto. (2000). Teori dan Praktek Sepak bola. Bandung. FPOK UPI

Sunarya, E. (2007). Filsafat Pendidikan Jasmani, Kesehatan dan Rekreasi. Bandung : FPOK UPI

Giriwijoyo, Sidik. (2010). Ilmu Faal Olahraga (Fisiologi Olahraga). Bandung : FPOK UPI.

Hidayat. (2010). Psikologi Olahraga. Bandung : Bintang WarliArtika

Goldblatt, D. (2011). The Football Book. London : Lentera Abadi.

Lopez, Shane J. \& Snyder, C.R. (2004). Positive Psychological Assesment : A Handbook of Models Measures. Washington DC : American Psychological Association.

Siregar, Sofyan. (2011). Statistik Deskriptif Untuk Penelitian. Jakarta: Raja Grafindo Persada.

Uchino, B. N. (2004). Social support and physical health: Understanding the health consequences of relationship. New Haven: Yale University Press.

Sarafino E. (2011). Health psychology: Biopsychosocial interactions (7th ed). Canada: John Wiley \& Sons, Inc. 
Y. Argo Trikomo. (1999). Pemulung Jalanan Yogyakarta: Kontruksi Marginalitas dan Perjuangan Hidup dalam Budaya-budaya Dominan. Yogyakarta : Media Pressindo.

Sekarwiri, E. (2008). Hubungan antara kualitas hidup dan sense of community pada warga DKI Jakarta yang tinggal di daerah banjir. (Skripsi). Universitas Indonesia. Depok.

Wardhani, Vini. (2006). Gambaran Kualitas Hidup Dewasa Muda Berstatus Lajang Melalui Adaptasi Instrument WHOQOL-BREF dan SRPB. (Tesis). Universitas Indonesia. Depok.

Rahayuningsih. (2012). Analisis Penderita Kualitas Hidup Kusta di Puskesmas Kedaung Wetan Kota Tangerang tahun 2012. (Tesis). Universitas Indonesia. Depok.

Nurbani, F. (2009). Dukungan sosial pada ODHA. (Skripsi). Universitas Gunadarma. Jakarta.

WHO. (1996). WHOQOL-BREF Instroduction, Administration, Scoring and Generic Version of Assessment. Geneva: World Health Organization.

WHO. (1997). WHOQOL : Measuring Quality of Life. Geneva: World Health Organization

Kementerian Kesehatan RI. (2013). Aku Bangga Aku Tahu. Jakarta: Kemenkes.

detikSport. (2012). Digelar di Bandung, Turnamen Street Soccer untuk Kaum Marjinal. Diakses dari : http://sport.detik.com/sepakbola/read/2012/02/23/ 140237/1849930/76/digelar-di-bandung-turnamen-street-soccer-untuk-kaum marjinal.

Homelessworldcup.org. (2015). Homeless World Cup Street Soccer Rules. Diakses dari : http://www.homelessworldcup.org/wp-content/uploads/2015/03/ Amsterdam2015-Rules.pdf

Rumah Cemara. (2014). Laporan Road To Homeless World Cup 2014. Diakses dari : http://rumahcemara.org/laporan-road-to-homeless-world-cup-2014/.

Rumah Cemara. (t.t). Profil Rumah Cemara. Bandung.

Kementerian Kesehatan Republik Indonesia. (2014). Situasi dan analisis penyalahgunaan Narkoba. Diakses dari http://www.depkes.go.id/resources/download/pusdatin/infodatin/infodatin-antinarkoba.pdf.

Carter. (2012). Study identifies issues affecting the quality of life of patients living with $H I V$. Diakses dari http://www.aidsmap.com/Study-identifies-issues-affectingthe-quality-of-life-of-patients-living-with-HIV/page/2202127/.

FIFA. (2014). Football for Hope at a glance. Diakses dari http://www.fifa.com/mm/document/afsocial/footballforhope/02/50/88/24/footb allforhopeataglance_neutral.pdf. 